\title{
Ferrer e Furtado: \\ A formação econômica de um espaço comum (1959-1963)
}

Bruno de Almeida Gambert ${ }^{1}$

Resumo: A proposta do artigo é comparar as obras La Economia Argentina, de Aldo Ferrer, e Formação Econômica do Brasil, de Celso Furtado com ênfase nos debates acadêmicos dos anos 1950-60 e privilegiando a visão que estes autores, situados no ambiente desenvolvimentista, lançam ao passado colonial. Nota-se que há contrastes entre os modos através dos quais cada um retrata o desenvolvimento econômico do seu país e para descrevê-los é fundamental estar atento ao período de produção dos estudos. No que tange à história econômica de ambas as nações, nos séculos XVI e XVII, eles apresentam a realidade colonial como um núcleo a partir do qual se configura o processo embrionário nacional, tanto no Brasil quanto na Argentina. Enquanto Furtado descreve o ciclo açucareiro no litoral que corresponde ao nordeste atual, Ferrer situa a atividade mercantil da área rio-platense no conjunto de territórios que formaram o Império Espanhol. Desta forma, revela-se o contraste entre a percepção de território vazio e de herança colonial ibérica. Almeja-se, por meio do cotejo das narrativas, evidenciar como estes intelectuais sul-americanos descrevem a trajetória de suas nações no contexto de meados do século XX.

Palavras-chave: Comparação Brasil e Argentina; História Latino-americana; História Econômica.

\section{Ferrer and Furtado:}

\section{The economic formation of a common space (1959-1963)}

Abstract: The proposal of the article is to compare the books "La Economía Argentina", by Aldo Ferrer, and "Economic Formation of Brazil", by Celso Furtado. It is noteworthy that there are contrasts between the ways in which each author portrays the economic development of his country and to describe them it is essential to be aware of the period of production of the works books, 1950 and 1960. Regarding the economic history of both the nations, in the sixteenth and seventeenth centuries, present colonial reality as a nucleus from which the national embryonic process takes shape, both in Brazil and in Argentina. While Furtado describes the sugar cycle on the coast that corresponds to the current northeast, Ferrer locates the commercial activity of the RioPlatense area in the set of territories that formed the Spanish Empire. In this way, the contrast between the perception of empty territory and Iberian colonial heritage is revealed. It is hoped, through the comparison of the narratives, to show how these South American intellectuals describe the trajectory of their nations in the context of the midtwentieth century.

Keywords: Comparison Brazil and Argentina; Latin American history; Economic History.

\footnotetext{
${ }^{1}$ Mestre em Ciências Sociais CPDA-UFRRJ. Graduado em História UFF. Professor de História da América UERJ. Doutorando em História UNIRIO. Título da Pesquisa: Direitos trabalhistas rurais em perspectiva comparada no Brasil e na Argentina (1944-1963). Correspondência: Rua do Riachuelo, 119. Ap. 1121. Lapa. Rio de Janeiro 20230080, RJ Brasil. dealmeidagambert@gmail.com.
}

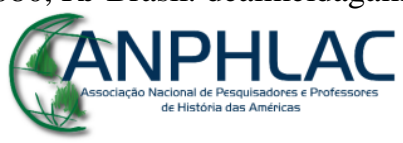

Revista Eletrônica da ANPHLAC, ISSN 1679-1061, №. 23, p. 285-313, Jul./Dez., 2017. http://revista.anphlac.org.br 
Recebido em: 14/03/2017

Aprovado em: 29/12/2017

\section{Introdução}

Nos anos 1950-60, o quadro político internacional após os conflitos da Segunda Guerra Mundial se organizou com os Estados Unidos ocupando o espaço de potência hegemônica se contraposto à União Soviética e aos demais países do boco socialista. Neste momento, o colonialismo sofreu retrocesso com o esfacelamento do Império inglês e a diminuição da área de influência da França com a independência das nações africanas que estiveram sob seu domínio. A Criação da Organização das Nações Unidas, em 1945, e da Comissão Econômica Para América Latina, em 1948, contribuíram para o surgimento de uma dinâmica nova nas relações entre nações, coerente com o novo quadro de poder. Neste período, a temática nacional-desenvolvimentista ganhou espaço nos países do chamado "Terceiro Mundo". Duas economias latino-americanas de destaque, a brasileira e a argentina, estavam no foco dos debates econômicos em função do processo de substituição de importações vigente à época.

Celso Furtado e Aldo Ferrer abordam a história econômica de suas sociedades no âmbito do movimento posteriormente conhecido como desenvolvimentismo. Nesta conjuntura, o saber acadêmico se dirige para o estudo do processo de formação dos mercados internos nacionais. No rastro do pensamento vigente, acreditam na possibilidade de reverter o quadro de carência econômico-social encontrado na região. No continente, tais concepções são contemporâneas à instituição do curso de sociologia nas universidades onde se inicia o diálogo entre a temática do desenvolvimento de matriz cepalina com as humanidades e os estudos históricos da nação. Eduardo Valdés descreve a aceitação dos estudos sociais destinados à temática do desenvolvimento no Brasil nos quais o passado é investigado através de suas relações comerciais e a superação do subdesenvolvimento torna-se uma meta. Através das narrativas econômicas, aponta-se o caminho para suplantar o quadro desfavorável da inserção do país no conjunto de nações (VALDES, 2003, p. 26).

As obras em análise foram escritas na conjuntura do início da segunda metade do século XX. Isto é, Celso Furtado publica no ano de 1959 e o argentino Aldo Ferrer, em 1963. Assim, as reflexões se alinham com a teoria econômica vigente tanto do

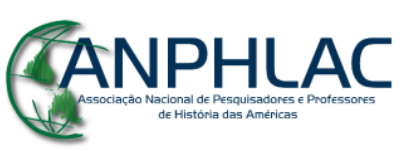

Revista Eletrônica da ANPHLAC, ISSN 1679-1061, №. 23, p. 285-313, Jul./Dez., 2017. http://revista.anphlac.org.br 
Brasil quanto da Argentina e interpretam a realidade nacional à luz de uma fração do pensamento econômico reconhecido como nacional-desenvolvimentista. O grupo se organiza seguindo a matriz de Raul Prebisch, responsável por elaborar a teoria da deterioração dos termos de troca dos produtos latino-americanos no comércio internacional. De acordo com tal teoria, com o passar dos anos, há perda no valor de troca dos produtos primários no mercado internacional quando comparados com os artigos industriais das nações desenvolvidas. Assim, o economista prevê uma perda de espaço cada vez maior das economias da parte sul do continente.

As nações classificadas no que se designa Terceiro Mundo englobam mais de dois terços da população mundial espalhados pelos cinco continentes. À luz dos autores, entende-se que, diferentemente dos Estados desenvolvidos do ocidente, estes países devem superar a última etapa de sua história e redefinir suas relações econômicas sob uma ordem nova na qual a alteração das suas estruturas mercantis e sociais se realiza sob a égide do desenvolvimento. Em grande parte, o atraso se refere aos sistemas coloniais exploratórios nos quais o arbítrio das sociedades estratificadas consiste em um conjunto de relações descritas como pré-capitalistas. A identificação do obstáculo tornase necessária devido a sua posterior suplementação através do processo industrial de substituições de importações que constrói um robusto mercado interno fundamental para o desenvolvimento econômico. Logo, destaca-se o sentido de história econômica colonial abordado por cada um dos autores, cada qual analisado em uma obra específica: "A Economia Argentina: De suas origens ao início do século XXI”, de Aldo Ferrer; "A Formação Econômica do Brasill", de Celso Furtado. Para ambos, a inserção da economia de seu país no mercado mundial internacional ocorre na cronologia que se estende do século XVI ao XVII. Contudo, o contraste entre as obras revela aspectos distintos da realidade colonial nos dois países.

Tendo em vista o diálogo entre os pesquisadores, proponho indagar quais fatores são evidenciados na realidade brasileira que pautam a narrativa histórica de Furtado, assim como aqueles destacados por Ferrer que, situados em cronologia aproximada, contribuem para o entendimento das estruturas político-sociais da economia argentina. Vale ressaltar que a história colonial torna-se objeto de estudo destes pesquisadores porque se dedicam à caracterização do subdesenvolvimento. Portanto, os séculos XVI, XVII e XVIII são remontados em suas estruturas principais para, no decorrer de sua

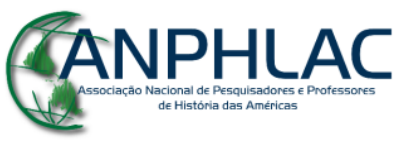

Revista Eletrônica da ANPHLAC, ISSN 1679-1061, №. 23, p. 285-313, Jul./Dez., 2017. http://revista.anphlac.org.br 
narrativa, serem ultrapassados por uma ordem econômica nova advinda do desenvolvimento do mercado interno. Em um período longo, os dados resgatados das formações coloniais descrevem os primeiros momentos da construção do que mais tarde se intitulou como economia nacional.

Os investigadores analisam os produtos exportados principais, os ciclos de comércio desenvolvidos, a geração de riqueza e a circulação de mercadorias. Em relação às estruturas que privilegiam as repetições da realidade comercial, elucidam a construção do sistema econômico de seus países no decorrer dos séculos e em conexão com o desenvolvimento dos bens materiais no ocidente europeu, centro do complexo sistema econômico mercantil conectado com o território sul-americano. Os desenvolvimentistas recuperam os elementos da formação da Argentina e do Brasil situados na contemporaneidade dos anos 1950-60, na qual os estudos em questão são redigidos. Desta forma, examinam eventos de séculos atrás, mas como todo tema histórico, refletem as questões do presente e, consequentemente, conferem um sentido novo à realidade vivida outrora.

A teoria da dependência das economias do cone sul é elaborada concomitantemente à pesquisa dos autores aqui retratados. Os problemas estruturais dos mercados coloniais são projetados nos seus quadros comerciais. Eles retardam o surgimento de um mercado interno autônomo com relações comerciais próprias regidas pela dinâmica da localidade. O desenvolvimento do Brasil, integrado à América Latina, é formulado pelos pensadores do ISEB e da CEPAL cuja interpretação nacionalburguesa guia os rumos da política econômica dos países. (BRESSER-PEREIRA, 2010, p. 18) Os dois autores refletem sobre questões seculares decorrentes do processo histórico, como a formação de grandes explorações agrícolas e minerais que propiciaram o surgimento de uma classe de grandes proprietários de terra e, consequentemente, a utilização de mão de obra nativa de forma compulsória, assim como a importação de mão de obra cativa.

Inicialmente, o território referente à Argentina contemporânea foi vinculado à rota de extração de prata situada em Potosí, região mineradora do Alto Peru. O porto oficial do Vice-Reino do Peru se encontrava em Lima, contudo, o atual Rio da Prata também servia de rota de escoamento dos bens metálicos destinados à coroa espanhola e ao contrabando. Em um vasto território colonial, a porção platina do império teve pouca

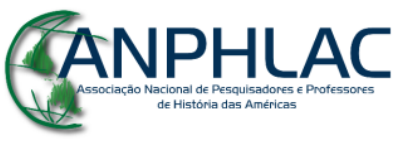

Revista Eletrônica da ANPHLAC, ISSN 1679-1061, №. 23, p. 285-313, Jul./Dez., 2017. http://revista.anphlac.org.br 
centralidade no quadro administrativo espanhol durante o primeiro século da colonização. As zonas mais povoadas do país se distribuíram pelo atual noroeste, sendo Córdoba e Tucumán importantes núcleos. Já no segundo século, os movimentos de ocupação do porto platino se destinavam ao comércio atlântico e a limitar a expansão dos portugueses no sul do continente.

A respeito dos contrastes entre a administração espanhola e lusitana nas Américas, vale assinalar que John Elliott, em seu ensaio de história comparada, sustenta que os portugueses destinam a atividade produtiva e mercantil americana à administração privada. Assim, delimitam a área das capitanias hereditárias e delegam a tutela do território à iniciativa de particulares. Os espanhóis, por sua vez, constroem uma estrutura de administração do Vice-Reino em um pequeno intervalo de tempo. Treze anos após a conquista de Hernán Cortez, em 1534, a coroa espanhola constrói o Vice-Reino da Nova Espanha, na atual cidade do México, ou seja, uma infraestrutura de poder criada diretamente pela ação do soberano, empregando os recursos da coroa. Os lusitanos, em outra direção, dedicavam seus esforços em direção ao oriente. É importante ressaltar que entre o reconhecimento e a nomeação do governador geral na cidade de Salvador, em 1549, tardou quase meio século. Então, após mais de quatro décadas, houve a implementação de uma estrutura de poder financiada pela coroa lusitana. Os portugueses demoraram aproximadamente meio século para se organizarem burocraticamente e sua cobiça mercantil se concentrava no leste. Sob a ótica de Elliott, os castelhanos tardaram menos, pois a sua coroa estava mais empenhada em conquistar e ordenar o território americano. (ELLIOTT, 2012, p. 32)

Em um primeiro momento, a área territorial mais dinâmica das regiões que hoje correspondem ao Brasil e à Argentina se situam próximas àquelas que desenvolvem duas atividades sustentadas pelas coroas ibéricas: as fazendas açucareiras no litoral brasileiro e a atividade mineradora de Potosí no Vice-Reino do Peru, atual Bolívia. Bem mais tarde, por volta de 1750, outro problema envolve os reinos ibéricos e cria uma série de embates territoriais entre Portugueses e Espanhóis. O território circundante ao Rio da Prata, a província de Sacramento e os Sete Povos das Missões estavam em disputa. Em meados do século XVIII, a região se tornou uma rota importante de contrabando de metais preciosos. Colonos portugueses habitavam a Província de Cisplatina e se envolviam no comércio clandestino. O tratado de Madri solucionou

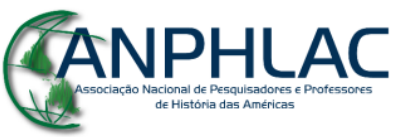

Revista Eletrônica da ANPHLAC, ISSN 1679-1061, №. 23, p. 285-313, Jul./Dez., 2017. http://revista.anphlac.org.br 
litígios e ordenou o território das possessões lusas e castelhanas na área. Neste período, a dinâmica dos impérios da península ibérica já tinha sido alterada. Com os governantes Bourbons, uma estrutura de administração buscou direcionar, com maior ênfase, os rendimentos de suas posses para o centro do poder monárquico. Desta maneira, em 1776, o Vice-Reino do Rio da Prata foi criado em Buenos Aires. (BRADING, 2012, p. 405)

Durante o governo de Dom Jose I, a administração do Marques de Pombal, conduziu as reformas administrativas na América portuguesa, sendo uma delas a transferência de sua capital de Salvador para o Rio de Janeiro em 1763. Concomitantemente às mudanças no governo colonial, o ciclo minerador desenvolvido na atual região sudeste do país, mais precisamente em Minas Gerais, estava interligado ao processo de exploração de ouro e diamantes já em plena expansão. Neste cenário, o novo centro de poder se instala e confere maior ênfase às atividades econômicas surgidas na região. A dinâmica produtiva estabelecida impulsiona a atual área do estado de São Paulo como polo de abastecimento das minas gerais e torna o Rio de Janeiro, cidade situada ao lado Baía de Guanabara, capital da colônia. Quando se aproximam os períodos, nota-se um intervalo de 13 anos entre a transformação de duas cidades portuárias importantes em sedes administrativas do poder imperial: no Rio de Janeiro, em 1763, e em Buenos Aires, em 1776. Coerente com o sistema tributário, verifica-se que as metrópoles concentram suas ações nos impostos da produção mineradora e fundam os centros administrativos em regiões estratégicas.

Nestes territórios, o período em destaque gerou zonas de exploração agrícola e mineração conectadas às metrópoles ibéricas. No século XIX, os regimes coloniais findam, a família real portuguesa vem ao Brasil e uma estrutura imperial instala-se na cidade do Rio de Janeiro. A formação da primeira junta, em 1810, os movimentos embrionários da independência e o consequente desmembramento do Vice-Reino do Rio da Prata configuraram a nação argentina. Em nosso estudo, destaca-se o peso distinto que Ferrer e Furtado associam ao período colonial de seus países. O primeiro atenta para o significado menor da experiência colonial na formação econômica argentina, o último, por sua vez, em posição distinta, vê na dinâmica colonial o início de um mercado interno decorrente da exploração aurífera associada à agricultura de exportação. Ambos os pesquisadores privilegiam o surgimento dos Estados Nacionais

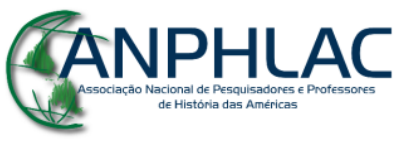

Revista Eletrônica da ANPHLAC, ISSN 1679-1061, №. 23, p. 285-313, Jul./Dez., 2017. http://revista.anphlac.org.br 
como força motriz de movimentos já existentes nos século XVI e XVII. Uma vez encerrada a relação de pertencimento aos impérios ibéricos, Argentina e Brasil passam por episódios diversos. Progressivamente, os países constroem uma união interna, consolidam o processo de constituição de um Estado e as relações de poder e infraestrutura demonstram continuidades relevantes no que tange às relações que os associavam à metrópole. Um olhar mais próximo ao debate acadêmico contemporâneo em relação à escrita das duas obras nos permite lançar luz a estes questionamentos.

\section{Breve análise teórica de história comparada.}

Os estudos históricos comparativos entre Brasil e Argentina possuem uma expressiva tradição. Entre eles, encontram-se os que se dedicam à abordagem dos governantes Getúlio Dornelles Vargas e Juan Domingos Perón. As análises sistematizam o modo de exercer o poder dos mandatários e se aproximam do debate referente ao populismo. Também há produções comparativas mais atuais que revelam questões diversas, como produção historiográfica, formação sindical e condições de vida do operariado urbano nos dois países. A investigação que propomos empenha-se em acrescentar saberes relativos à narrativa da história econômica presente na pesquisa dos autores. Acredita-se que o debate sobre um aspecto das obras de Aldo Ferrer e Celso Furtado preenche uma lacuna nos estudos comparativos ${ }^{2}$ e abre perspectiva para a discussão sobre os intelectuais dos anos 1950-1960 que pensavam os sistemas econômicos dos séculos XVI e XVII no contexto latino-americano.

Um teoria tornou-se bastante conhecida nos estudos de história comparada por analisar e contrastar sociedades sincrônicas. Elaborado por Marc Bloch (1998), o método consiste, em seu núcleo, na abordagem de sociedades que possuem características estruturais semelhantes, que ocupam espaços geográficos comuns e estabelecem relações entre si no período histórico estudado. Isto é, região e cronologia histórica aproximadas na abordagem de países distintos, mas dotados de aspectos

\footnotetext{
${ }^{2}$ As mais diversas correntes de estudos comparativos históricos podem ser citadas. A tradição de comparar Vargas e Perón tem destaque nas obras de CAPELATO (1998) e DEVOTO; FAUSTO (2009). ALIMONDA (1982) e RIBEIRO (2006) comparam as duas nações em sua perspectiva rural. FERRERAS (1995) compara questões de trabalho e condições de vida no início do século XX. SOUZA (2010) faz uma comparação sociológica que envolve o sindicalismo urbano contemporâneo. SILVA (2011) promove o diálogo disciplinar entre a historiografia dos dois países no que se refere ao início do século XX.
}

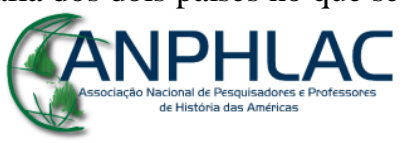

Revista Eletrônica da ANPHLAC, ISSN 1679-1061, №. 23, p. 285-313, Jul./Dez., 2017. http://revista.anphlac.org.br 
comuns. Em Os reis taumaturgos, o pensador dos Analles contrapõe dados específicos sobre os rituais de cura régia realizados pelos monarcas dos reinos de França e Inglaterra, entre o século XII e o XVIII. Bloch redigiu sua obra no pós-guerra do primeiro conflito armado europeu com proporções mundiais do século XX. A metodologia adotada pelo autor permite integrar e romper os elementos da historiografia nacionalista em um momento crucial no qual a forte rivalidade beligerante dos países do continente ocupa o cenário político.

Acredita-se que pensar a respeito de intelectuais oriundos do Brasil e da Argentina nos moldes apresentados é relevante devido às similitudes que a teoria do investigador francês aporta à questão, uma vez que Ferrer e Furtado vivem em zonas geográficas próximas e estabelecem relações entre si. Entre os dados estruturais que apresentam sobre os seus países consistem aqueles nos quais há um traço comum, como a relação com os impérios Ibéricos no decorrer dos séculos XVI e XVII. Contudo, lembra-se que os elementos formativos dificultam a aplicação direta de uma teoria setentrional nas esferas do sul, pois a análise referente a tais espaços considera a sistematização de informações sobre nações que outrora foram colônias. Logo, é necessário assinalar especificidades, como a presença não só da população pertencente às sociedades originárias do continente, mas também cativos, alforriados e livres de ascendência africana, colonos europeus e uma grande quantidade de mestiços. Assim, as composições sociais, políticas e econômicas específicas pouco se adequam aos quadros estruturais criados para refletir sobre os reinos europeus.

A teoria de história conectada de Gruzinski (2012) é outra perspectiva através da qual é possível cotejar as ideias em debate. Em A água e o dragão: ambições europeias e mundialização no século XVI, o autor estrutura uma narrativa referente à expansão mundial europeia executada pelos reinos de Portugal e Espanha. A obra explora componentes de simultaneidade como a conquista sobre o México-Tenochtitlán e as ações portuguesas na China voltadas ao domínio da praça comercial de Cantão. Tanto na Ásia quanto na América, os europeus impunham ordem por meio da guerra às populações locais. Os objetivos da conquista e a instauração de domínios ibéricos possuem traços comuns nas áreas mais longínquas do globo. Conectar as histórias de processos simultâneos torna a escrita disciplinar um processo complexo e internacional, atende a análise dos feitos de época e afasta a historiografia dos círculos de

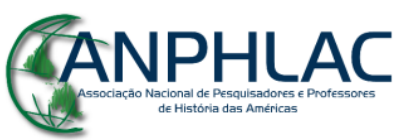

Revista Eletrônica da ANPHLAC, ISSN 1679-1061, №. 23, p. 285-313, Jul./Dez., 2017. http://revista.anphlac.org.br 
conhecimento circunscritos ao Estado-nação. $\mathrm{O}$ estudo que propomos dialoga com o modelo estruturado por este pensador francês no que concerne ao problema internacional simultâneo. Contudo, a perspectiva se inverte, pois se concentra na visão de economistas-historiadores sobre sociedades dominadas por reinos ibéricos. Nos territórios enfatizados, os problemas de comércio internacional de recursos primários e as formas compulsórias de sistema de trabalho são ressaltados.

Maria Ligia Prado analisa os modelos de história comparada, transnacional e conectada que ultrapassam a barreira disciplinar circunscrita ao âmbito do Estado-nação produzidos na América Latina. Os estudos que aproximam Brasil e Estados Unidos são um dos aspectos destacados. Ela esclarece que a característica de competição entre os estados nacionais pode ocupar o centro da abordagem em detrimento do objeto a ser comparado, de maneira que se prejudica o foco da comparação e passa a refletir estritamente a superioridade de uma das partes. (PRADO, 2011, p. 20) A autora reconhece os trabalhos pautados pela teoria da dependência dos anos 1960-70 como permeados por temas totalizadores da macro história, pois partem de conceitos supostamente comuns no continente, como atraso, pobreza e subdesenvolvimento. (PRADO, 2011, p. 12) A CEPAL tornou-se um órgão irradiador do pensamento econômico para as demais ciências humanas no período. Ferrer e Furtado estabelecem entre si relações tanto amistosas, como profissionais, e se conectam ao conjunto de pensadores reconhecidos como desenvolvimentistas. A presente análise questiona pontualmente as premissas generalizadoras a respeito da formação econômica latinoamericana e promove indagações sobre a organização de um espaço comum.

\section{Os autores.}

No que tange ao conteúdo da abordagem econômica, há uma variedade de leituras que aproximam Celso Furtado e Raul Prebisch ${ }^{3}$. Realizadas por economistas, as investigações se debruçam sobre a análise do Estruturalismo latino-americano. A iniciativa de Prebisch em reconhecer um fator específico das economias da parcela sul do continente é reconhecida por Celso Furtado que a sistematiza e redimensiona. O pesquisador brasileiro traduz o problema econômico em um quadro abrangente e

\footnotetext{
${ }^{3}$ MACEDO, 2002. LORA; MALLORQUÍN, 1999. D’ARBO, 2002.
}

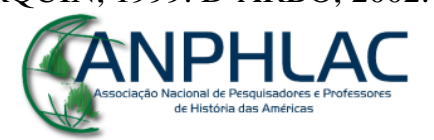

Revista Eletrônica da ANPHLAC, ISSN 1679-1061, №. 23, p. 285-313, Jul./Dez., 2017.

http://revista.anphlac.org.br 
incorpora as vertentes históricas, políticas e sociais encontradas no contexto sulamericano, como a colonização ibérica e a forte hierarquia social.

Nascido em 1901, Prebisch se distancia em mais de uma década dos autores de nossa comparação. As investigações anteriores identificam a contribuição de Prebisch e Furtado no bojo do pensamento cepalino. De maneira distinta, o foco da presente comparação incide na abordagem histórica dos autores que revelam a formação econômica de seus países. Por isso, a obra de Aldo Ferrer torna-se uma opção mais pertinente. Diferentemente de Prebisch, Ferrer é uma figura menos conhecida do leitor brasileiro. Vale ressaltar a inserção temporal dos três autores: Raul Prebisch (19011986) é o mais velho e pioneiro das ideias desenvolvimentistas. Por sua vez, Celso Furtado (1920-2004) e Aldo Ferrer (1927-2016), seus discípulos brasileiro e argentino, respectivamente, trabalham os temas econômicos da região em que se inserem em consonância com o pensamento do seu mestre. O trio publicou a obra Deuda y soberania em 1984, e unidos lançaram luz ao grave desafio daquela conjuntura, os ciclos inflacionários.

Espaço privilegiado para o pensamento econômico regional, a CEPAL foi presidida por Prebisch entre os anos de 1950 e 1963. Professor da Universidade de Buenos Aires e gerente do Banco Central Argentino, o pensador tornou-se um dos interpretes da economia latino-americana mais conhecidos de sua época. Os estudos do autor refletem sobre a perda de valor contínuo das exportações agrícolas latinoamericanas no comércio internacional com o passar dos anos, resultando em um desequilíbrio negativo para os países agrários exportadores. Enquanto os itens industriais importados das economias industrializadas aumentam seu valor agregado sustentados pelo intenso processo tecnológico, os agrícolas decrescem. A teoria do intelectual de Tucuman estrutura a base dos estudos posteriores cuja ênfase está na delimitação do espaço relativo dos países latino-americanos no comércio internacional.

Aluno de Prebisch no curso de economia da Universidade de Buenos Aires, Aldo Ferrer deu continuidade aos seus trabalhos e se propôs ao estudo de temas específicos, como a história econômica nacional. Nascido em 1920, na cidade capital rio-platense, fez parte da geração de economistas nacional-desenvolvimentistas da Argentina, ocupou cargos de ministro da economia e trabalhou no governo militar de Levingston e Lanusse em 1970-1971. Também esteve no Chile, como ministro de

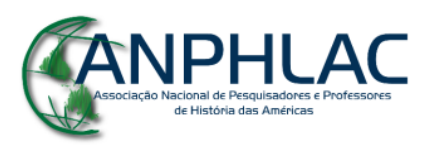

Revista Eletrônica da ANPHLAC, ISSN 1679-1061, №. 23, p. 285-313, Jul./Dez., 2017. http://revista.anphlac.org.br 
Salvador Allende na Unidade Popular nos anos de 1971-1973, assim como participou do comando do Banco da Província de Buenos Aires nos anos de redemocratização. Além disso, integrou o governo de Raul Alfonsín da União Cívica Radical (1983$1986)^{4}$. Recentemente, em uma entrevista para a televisão pública de seu país, o economista portenho relatou que a escrita de Formação Econômica Argentina realizouse após a leitura de Formação econômica do Brasil, de Celso Furtado ${ }^{5}$. Em seu livro, Ferrer dialoga com a obra do brasileiro em sua narrativa.

Nomeado por Raul Prebisch para dirigir a divisão de desenvolvimento da Cepal, Celso Furtado teve relações de proximidade com os pensadores argentinos. Nascido na Paraíba em 1920, Furtado teve sua educação primária no Recife. Oriundo de classe abastada no campo, graduou-se em direito no Rio de Janeiro e, em seguida, especializou-se no exterior, obtendo o título de doutor pela Universidade Sorbonne. Em 1959, retornou ao Brasil onde ocupou postos importantes da administração pública. Participou dos governos de Juscelino Kubistchek, Jânio Quadros e João Goulart, representantes, respectivamente, de três agremiações partidárias distintas, PSD, UDN, $\mathrm{PTB}^{6}$. Furtado esteve à frente da SUDENE, órgão destinado a promover $\mathrm{o}$ desenvolvimento econômico da região nordeste brasileira e se insere como um intelectual responsável pela continuidade do pensamento de Prebisch desenvolvido na Cepal. Possui estudos de síntese sobre a formação econômica latino-americana e artigos com interesse na economia venezuelana.

\section{O historiador fruto de seu tempo.}

Após 1945, o cenário político-econômico cria uma nova hierarquia de poder em âmbito internacional. As nações sul-americanas intensificam o processo de industrialização por meio de um modelo descrito como substituição de importações. A

\footnotetext{
${ }^{4}$ Informações biográficas sobre Ferrer podem ser encontradas em ROUGIER, 2014.

${ }^{5}$ FERRER, Aldo. Entrevista concedida a Cristian Mucci. Terceiro bloco. Em 02/05/2015. Disponível em: https://www.youtube.com/watch?v=hjIY-_mUCKE Acesso em: 14/03/2016. Nesta entrevista, Ferrer cita Hélio Jaguaribe (ISEB); encontra-se com seu grande amigo Celso Furtado em Washington D.C. (EUA). Conheceu o livro A formação econômica do Brasil e constatou que o método de trabalhar de Furtado se encaixava na história Argentina, propondo-se, então, a analisa-lo para o caso argentino. Como resultado, surgiu a obra A economia Argentina.

${ }^{6}$ As três legendas partidárias são, respectivamente: Partido Social Democrático; União Democrática Nacional; Partido Trabalhista Brasileiro.
}

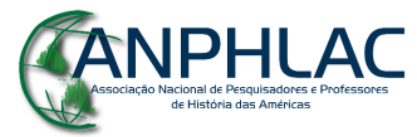

Revista Eletrônica da ANPHLAC, ISSN 1679-1061, №. 23, p. 285-313, Jul./Dez., 2017. http://revista.anphlac.org.br 
crença no liberalismo como caminho de desenvolvimento e equidade se enfraqueceu ainda mais nos anos 1950 e, desde então, os debates econômicos se intensificam e a rota desenvolvimentista norteia os anseios das nações independentes.

Segundo Arturo Escobar, em 1948, o Banco Mundial classifica os países de acordo com suas rendas per-capita, em dólares, o que estima a possível renda média mensal de seus habitantes. Em um pequeno gesto classificativo, consideram-se pobres os países que alcançam quantia inferior a US\$100 per-capita. Então, dois terços do mundo são automaticamente categorizados como pertencentes ao Terceiro Mundo. A solução para a pobreza detectada, segundo os operadores financeiros internacionais, atravessa o desenvolvimento econômico. Via de regra, o caminho para alcançá-lo consiste na luta contra a pobreza, o que cria a necessidade de investimentos em amplos setores da economia e parcerias com agentes do mundo desenvolvido que, constantemente, oferecem pacotes tecnológicos para áreas destinadas à extração de recursos naturais, para a agricultura e o comércio exterior. Este contexto é conhecido como desenvolvimentista e o paradigma do crescimento das economias subdesenvolvidas movimenta a política das nações sul-americanas. $\mathrm{O}$ mercado se ajusta de maneira dolorosa para superar o atraso que ganha destaque na agenda pública governamental. (ESCOBAR, 2007, p. 51)

No campo acadêmico, os estudos que abordam as temáticas do desenvolvimento ganham evidência. Celso Furtado e Aldo Ferrer identificam como sistema econômico desejável aquele no qual o capitalismo, com base nacional, assegura o seu amplo desenvolvimento. Devido a esta perspectiva, as suas teorias são classificadas como nacional-desenvolvimentistas. Este modelo valoriza o crescimento e o bem estar das indústrias, principalmente as formadas por capitais de seu próprio país. Ademais, defende a inserção da nação no cenário tecnológico produtivo por meio do desenvolvimento de setores de sua economia, além da resolução de entraves estratégicos, entre os quais, assinalam-se: a necessidade de poupança e investimento, escolaridade da população e a enorme concentração de riquezas. O contexto mencionado por Escobar torna atrativa a obra histórica dos pesquisadores. Centrado nas relações dos Estados Unidos com o mundo do pós Segunda Guerra, o antropólogo colombiano enfoca os aspectos críticos do nacional desenvolvimentismo. Ele ressalta que estadistas nacional-desenvolvimentistas promoveram reformas no país,

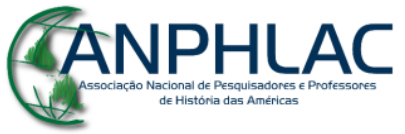

Revista Eletrônica da ANPHLAC, ISSN 1679-1061, №. 23, p. 285-313, Jul./Dez., 2017. http://revista.anphlac.org.br 
impulsionaram o crescimento das empresas nacionais e, contrariamente aos postulados formulados, em uma etapa posterior, atrelaram-se ao capital internacional sob a hegemonia estadunidense e alteraram de forma mínima as estruturas sociais vigentes.

Raul Prebisch lidera a CEPAL entre os anos de 1950 e 1963. Tanto a formação econômica clássica quanto a experiência profissional permitem que o autor desenvolva reflexões nas quais demonstra que as teorias criadas no centro do mundo capitalista não funcionam da mesma maneira na periferia. Com a liderança de Prebisch, o pensamento econômico de uma fração de argentinos ganha oficialidade para representar o continente. Já em relação aos brasileiros, verifica-se que eles são incorporados ao seu projeto, entre os quais, destaca-se a presença do economista Celso Furtado. Também é importante assinalar que uma vertente do pensamento econômico desenvolvimentista brasileiro elabora-se no Instituto Superior de Estudos Brasileiros (ISEB) ${ }^{7}$, formado por pensadores do Rio de Janeiro e São Paulo. Neste espaço, enfatiza-se a reflexão sobre políticas públicas para o desenvolvimento do país, muitas das quais em consonância com o que estava sendo debatido no órgão das Nações Unidas para a economia latinoamericana. Eles recebiam investimentos públicos e da federação de comerciantes brasileiros.

Conforme mencionado, os autores argentino e brasileiro retornam ao passado da modernidade europeia para contextualizar os primeiros passos da formação econômica de suas nações. Nesta tarefa, recorrem ao circuito comercial europeu dos reinos "mercantilistas" e descrevem o surgimento de espaços exploratórios e produtivos que, posteriormente, tornam-se as nações sul-americanas. Ambos elucidam a construção de redes comerciais que impulsionam os vestígios iniciais do que designam como mercado interno, anterior à independência e promotor da nação. Com as dúvidas do tempo ao qual pertencem, começam a investigação do passado com perguntas que atendem anseios contemporâneos do sistema econômico de seus países e, dessa maneira, recuam de forma específica e pontual aos séculos XVI e XVII. Através do deslocamento temporal, almejam decifrar aspectos econômicos que, quando resgatados, ajudam a esclarecer características conjunturais da discussão desenvolvimentista dos anos 1960. Sendo assim, o presente artigo propõe um debate motivado pela seguinte questão: os intelectuais reconhecem as atividades econômicas desenvolvidas em seus territórios de

\footnotetext{
${ }^{7}$ Mais informações sobre o ISEB, ver: PRADO, 2010.

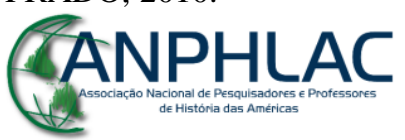

Revista Eletrônica da ANPHLAC, ISSN 1679-1061, №. 23, p. 285-313, Jul./Dez., 2017. http://revista.anphlac.org.br
} 
análise como similares? Tais atividades formariam um espaço econômico periférico e indiferenciado? Para se aproximar da solução das indagações, é imprescindível examinar as narrativas construídas pelos intelectuais e situá-las na conjuntura em que foram escritas.

\section{Furtado e o complexo açucareiro do litoral brasileiro.}

O quadro construído por Celso Furtado sobre a história da formação econômica brasileira no período colonial possui dois itens que merecem ênfase: a opção de Portugal por montar um complexo agrícola e a caracterização das empresas coloniais que orientam a formação econômica nacional. Na primeira parte, no item $\mathrm{V}$, em que aborda temas dos séculos XVI e XVII, ele analisa As colônias de povoamento do hemisfério norte onde, segundo o autor, esta parte do mundo anglo-saxão possuía uma lógica específica de ocupação do solo que a diferencia das demais nações ibéricas. No primeiro ponto, Da expansão comercial à empresa agrícola, a dificuldade do reino português de concentrar recursos e manter sua posição no Atlântico Sul quinhentista é descrita em um momento no qual os demais países europeus buscam estabelecer posses nestes limites. Logo, uma das formas de evitar a presença estrangeira no litoral brasileiro foi a ocupação do espaço por meio da atividade produtiva e a sua transformação em elemento atrativo para o reino lusitano. No entanto, como Furtado destaca, a presença dos flamengos (Antuérpia) como sócios de Portugal permite a obtenção de recursos pelo país e a circulação do seu produto agrícola em uma das principais praças de comércio da Europa renascentista (FURTADO, 1963, p. 19).

A problemática relacionada ao emprego da mão de obra evidencia as peculiaridades do modelo nacional. Celso Furtado enfoca a impossibilidade de ocupar os engenhos nordestinos com mão de obra europeia, pois naquela conjuntura, para cumprir este objetivo, seria necessário remunerar os trabalhadores com salários acima da média encontrada em suas nações, o que estava fora das possibilidades da indústria açucareira. Então, a solução encontrada foi a importação de trabalhadores cativos. (FURTADO, 1963, p. 21) Há tentativas de utilização de mão de obra indígena. Esta, porém, não se apresenta tão lucrativa quanto o comércio de seres humanos africanos, já que o tráfico de pessoas escravizadas rendia impostos à metrópole. A seu ver, esta

\section{CANPHLAC}

Revista Eletrônica da ANPHLAC, ISSN 1679-1061, №. 23, p. 285-313, Jul./Dez., 2017. http://revista.anphlac.org.br 
singularidade marca a formação da mão de obra do complexo açucareiro brasileiro, mas outros autores se debruçam sobre o tema em perspectivas diversas. Fernand Braudel, por exemplo, descreve outros detalhes sobre a utilização de mão de obra no domínios distantes do centro europeu. Aldo Ferrer, por sua vez, enfatiza elementos que constituem a forma pela qual se recrutava mão de obra nos domínios coloniais espanhóis nas cercanias do Rio da Prata.

A natureza tropical dos produtos coloniais marca o segundo ponto que destacamos da narrativa de Furtado. De acordo com a argumentação sustentada, identifica-se uma diferença entre o deslocamento populacional motivado por atividades comerciais e aqueles cujo objetivo consiste meramente na habitação em outro território. Contraposta às áreas voltadas ao povoamento, a colônia de exploração econômica tem fins de imigração. Arrisca-se dizer que o autor identifica uma complementariedade agrícola comum ao pensamento de sua época. Seguindo as linhas principais do raciocínio do autor, compreende-se que os territórios tropicais poderiam gerar artigos não cultiváveis em solo europeu por questões climáticas. Em vista disso, os colonos se deslocaram para os espaços próximos aos trópicos dominados pelas metrópoles ibéricas para realizar sua produção. Por outro lado, os territórios americanos de clima mais ameno cultivavam gêneros agrícolas similares aos encontrados na Europa. Logo, tal complementariedade resulta no retardamento de implementação das colônias destinadas ao povoamento.

Fernando Novais reflete sobre os dados estruturantes no estabelecimento de um sistema colonial e estabelece considerações sobre o sentido da colonização. O historiador ressalta que a ação de povoamento se apresenta como uma característica constante em muitos tipos de colonização europeia. Sendo assim, um dos fatores que separa a experiência das Américas inglesa e portuguesa consiste em sua integração ao sistema mercantilista europeu. Neste processo, a dinâmica econômica se concentra no interior enquanto as zonas destacadas pela fixação populacional de colonos ocupa a marginalidade. A classificação dos tipos de colônia dual e opostas pouco afere dados à estas realidade. A seu ver, tais classificações são

um economismo que vicia a análise, que se pretende globalizadora [...] ao tentarmos fixar as categorias essenciais desse processo histórico, não buscamos de forma alguma os denominadores comuns presentes

\section{GANPHLAC}

Revista Eletrônica da ANPHLAC, ISSN 1679-1061, №. 23, p. 285-313, Jul./Dez., 2017.

http://revista.anphlac.org.br 
necessariamente em todas as manifestações concretas. (NOVAIS, 1969, p. 63)

As categorias econômicas para a leitura do período colonial americano são problematizadas e redimensionadas após críticas. Ao final dos anos 1960, o tipo de colonização e os sistemas de trabalho geravam controvérsias.

Furtado menciona a colonização da América espanhola com ênfase na característica mineradora que ocupou um papel central nos quadros administrativos coloniais. Segundo a sua visão, os sistemas agrícolas ocupavam um papel secundário no primeiro momento do domínio castelhano. O autor salienta que Portugal não possuía recursos similares para investir e dependia dos cultivos agrícolas para manter suas possessões. Deste modo, a exploração mineradora em larga escala demora a se estabelecer em seus domínios. Os exemplos de Portugal e Espanha marcam de forma enfática os pontos que contrastam entre o litoral brasileiro das demais áreas criadas naquele momento pela coroa de Castela. A seu ver, os castelhanos seguiram precocemente o caminho dos metais.

\begin{abstract}
Houvesse a colonização espanhola evoluído nesse sentido (cultivos agrícolas) e muito maiores teriam sido as dificuldades enfrentadas pela empresa portuguesa para vencer. A abundância de terras da melhor qualidade para produzir açúcar de que dispunha - terras estas bem mais próximas da Europa -, a barateza de uma mão de obra indígena mais evoluída do ponto de vista agrícola, bem como o enorme poder financeiro concentrado em suas mãos, tudo indica que os espanhóis podiam haver dominado o mercado de produtos tropicais - particularmente o açúcar - desde o século XVI. A razão principal de que isso não haja acontecido foi, muito provavelmente, a própria decadência econômica da Espanha... ...Cabe portanto admitir que um dos fatôres do êxito da empresa colonizadora agrícola portuguesa foi a decadência mesma da economia espanhola, a qual se deveu principalmente à descoberta precoce dos metais preciosos. (FURTADO, 1963, p. 25-26)
\end{abstract}

Os historiadores pouco se debruçam sobre a proposição de outras opções factuais da história e, por isso, classificam os desdobramentos desinteressantes à análise disciplinar. No entanto, o caso exposto acima evidencia a visão projetada pelo autor que reflete sobre as chances perdidas pela coroa espanhola. De acordo com o seu ponto de vista, o domínio espanhol poderia ter ocupado mais o mercado agrícola de produtos de clima tropical inviabilizando as plantações dos lusitanos, mas, por fatores específicos, não pôde aproveitar a oportunidade. Também responde as possíveis indagações sobre os

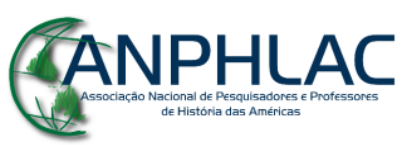

Revista Eletrônica da ANPHLAC, ISSN 1679-1061, №. 23, p. 285-313, Jul./Dez., 2017. http://revista.anphlac.org.br 
motivos que dificultaram o reino castelhano de se tornar senhor da produção e do comércio açucareiro nos séculos XVI e XVII. Neste quadro, entende-se que a concentração das atividades coloniais nas explorações de metais preciosos fez a coroa espanhola transformar-se num grande importador de manufaturas no mercado do continente europeu. Em uma segunda etapa da colonização, no período bourbônico (século XVIII), a opção mineradora coexistiu com sistemas agrícolas desenvolvidos nas regiões tropicais do então decadente império (BRADING, 2012, p. 421).

Celso Furtado privilegia as escolhas econômicas tomadas pela sociedade e a intencionalidade econômica dos habitantes ao povoar um determinado território. A crítica a este tipo de pensamento sugere outra perspectiva a respeito do impulso econômico formativo das colônias de povoamento. O papel dado à intenção do colono em permanecer no território responde pelo modelo de sociedade implementado, assim como o posicionamento geográfico das explorações promove a instalação de empresas coloniais destinadas aos produtos tropicais. Como mencionado, o sistema comercial formado na costa brasileira se insere nas estruturas mercantis da colonização ibérica na qual artigos tropicais abasteciam as principais praças comerciais europeias.

\section{Periferias de um sistema mundial.}

Em 1967, Braudel publica o estudo Civilisation Matérielle, Économie et Capitalisme, $X V^{e}-X V I I I^{e}$. Nesta obra, verifica-se uma perspectiva histórica peculiar sobre os dados relativos à formação do capitalismo nos reinos cristãos centrais no período moderno entre 1401-1800. O sistema que delineia representa as relações comerciais formativas do ocidente europeu. Dinâmicas, as estruturas de poder estabelecem uma alteração geográfica na qual a parte mediterrânica do continente tem sua hegemonia alterada. Dos reinos italianos da Renascença às praças comerciais de destaque, perpassando Antuérpia, Flandres, Amsterdã e, finalmente, chegando a Londres. Em cada local, o autor identifica a vida de uma sociedade com traços próprios. A obra de Braudel é vasta e consiste em uma trilogia de fôlego que narra a história da vida material e das trocas comerciais das sociedades europeias. Um trajetória econômica de longa duração capaz de identificar elementos gerais de sua sociedade. Abaixo,

\section{CANPHLAC}

Revista Eletrônica da ANPHLAC, ISSN 1679-1061, №. 23, p. 285-313, Jul./Dez., 2017.

http://revista.anphlac.org.br 
elucidam-se as afirmações através de um fragmento breve no qual expõe a ideia de Sistema Mundo:

\begin{abstract}
Resumindo, do exame de um caso particular deduzimos que uma economia mundo é uma soma de espaços individualizados, econômicos e não econômicos agrupados por ela; que a economia mundo representa uma enorme superfície (em princípio, é a mais vasta zona de coerência, em determinada época, em uma região determinada do globo); que, habitualmente, ela transcende os limites dos outros grupos maciços da história. (BRAUDEL, 1978, p. 14)
\end{abstract}

$\mathrm{O}$ relato das trocas econômicas entre as nações se traduz numa estrutura maior reconhecida na categoria braudeliana de Sistema Mundo que enriquecerá a nossa comparação histórica em contraste com os pensadores latino-americanos, pois há uma coincidência temporal, os séculos XVI e XVII, presente na obra dos três teóricos. O pensador da segunda geração dos Annales oferece uma descrição da formação material das sociedades europeias. Assim, relata uma das partes centrais de um período aqui analisado pela perspectiva de Furtado e Ferrer. Há momentos em que o pensador francês retrata aspectos comuns da periferia de seu Sistema Mundo que tocam o foco das abordagens de Furtado e Ferrer. Entretanto, a visão do pensador europeu pouco coincide com as dos autores latino-americanos.

Um dos itens privilegiados na obra de Braudel diz respeito ao trabalho compulsório, seja livre ou cativo. Consoante o pensador francês, há uma classificação entre os modelos de mão de obra encontrados tanto no centro quanto na periferia do sistema. Nas últimas áreas, as condições de trabalho são piores à medida que o espaço analisado se distancia do centro. Deste modo, o trabalho cativo corresponde a uma parte longínqua, em local no qual existe pouca divisão de trabalho, e a remuneração e as condições de trabalho são deterioradas. O conceito de periferia braudeliano abarca não só regiões dos impérios coloniais europeus, mas também as regiões do próprio continente que se encontram em um estágio intermediário de desenvolvimento políticoeconômico, como os Balcãs. O tempo em que o pensador dos Annales constrói e descreve o sistema é fluído, altera-se de acordo com a região e percorre um período que se estende do século XIV ao XVIII. Abaixo, adiciona-se uma passagem em que o autor esclarece seu conceito de periferia:

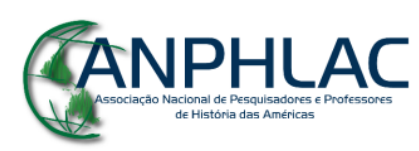

Revista Eletrônica da ANPHLAC, ISSN 1679-1061, №. 23, p. 285-313, Jul./Dez., 2017. http://revista.anphlac.org.br 
As ambiguidades dissipam-se quando penetramos nas regiões periféricas. Aí, o erro é impossível: São regiões pobres, arcaizantes, onde o estatuto social determinante é muitas vezes a servidão ou mesmo a escravatura. São regiões que mal entraram na economia monetária. Regiões em que a divisão do trabalho mal começou; em que o camponês se ocupa de todos os ofícios ao mesmo tempo; em que os preços monetários, quando praticados, são irrisórios. Aliás, toda a vida é muito barata é, por si só, sinal de subdesenvolvimento. (BRAUDEL 1978, p. 30)

Pouca presença de trocas monetárias, baixa divisão do trabalho e a suposta vida barata são elementos que traduzem aspectos comuns da realidade periférica. Aproximando as experiências de Furtado com a descrição de Sistema Mundo de Braudel, destaca-se uma conexão entre os dois dados. Os espaços centrais de interlocução do comércio açucareiro português na Europa que o economista brasileiro enfatiza são, coincidentemente, naquele momento, os focos do deslocamento do poder europeu narrados pelo intelectual francês, isto é, aqueles próximos aos Países Baixos, cujo centro é o seu porto principal na cidade de Antuérpia, atual Bélgica. Ali, os lusitanos conseguem vender sua mercadoria e recorrem a financiamentos que possibilitam a continuidade de suas atividades com surgimento de novos engenhos.

Furtado analisa, pontualmente, um evento da formação da economia açucareira no nordeste colonial. Contudo, o conceito de periferia tem pouca marcação na obra analisada. No século XVII, as posses do litoral brasileiros são uma das mais lucrativas atividades comerciais portuguesas. Mais tarde, temas sobre centro-periferia compuseram parte da Teoria da Dependência. Em 1959, estas formas de sistematização estavam pouco claras. Nas décadas seguintes, a teoria que incorpora o Brasil neste modelo é levada a cabo por um grupo de pesquisadores, com destaque para Fernando Henrique Cardoso e Enzo Faletto (1970). Em outra vertente, a obra de Rui Mauro Marini funda escola entre os latino-americanos deportados pelos regimes militares. A análise da dialética da dependência apresentada pelo grupo influencia os estudos realizados no Chile e no México entre os anos 1970-1980. Nos aspectos políticos da produção acadêmica, a teoria da dependência utiliza dados que os estudos de história econômica traduzem da realidade (TRASPADINI; STEDILE, 2011, p. 80-95).

Retomando o debate dos autores dos anos 1960 sobre aspectos econômicos dos XVI e XVII no tema já visitado da mão de obra ocupada no complexo açucareiro, notase que, quando se aproxima a descrição de Sistema Mundo construído pelo historiador francês ao conteúdo selecionado por Furtado, o litoral brasileiro encaixa-se com

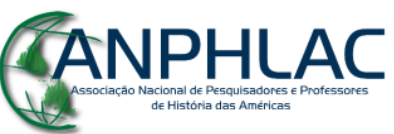

Revista Eletrônica da ANPHLAC, ISSN 1679-1061, №. 23, p. 285-313, Jul./Dez., 2017. http://revista.anphlac.org.br 
desenvoltura na periferia do Sistema Mundo europeu. Os fatores que permitem tal associação são a presença do trabalho cativo, pouco especializado e não remunerado, além da distância física do centro hegemônico e da baixa monetarização (interna). Na dita comparação, a economia açucareira dificilmente teria recursos para importar trabalhadores europeus. Impossibilitada de oferecer altos salários para este tipo de trabalhador, utiliza-se de mão de obra escrava devido a seu preço e justificada pela indisponibilidade de recurso para a remuneração dos trabalhadores livres. Os fatores explicitados apontam questões comuns à periferia com uma especificidade nacional. No entanto, Braudel constrói um Sistema Mundo no qual um dos traços que situa um território na periferia seria a utilização de trabalho em condições piores na medida em que nos afastamos do centro. O pensador francês não se refere especificamente ao caso brasileiro, porém a sua sistematização tipifica importantes aspectos desta realidade e permite a inserção do modelo descrito do complexo açucareiro brasileiro no século XVI e XVII em um ponto distante do centro do sistema por ele construído.

O molde periférico delimita menos distinções cada vez que nos distanciamos do centro. Isto é, quanto mais longe dos centros dinâmicos, torna-se menor a divisão do trabalho, os fluxos monetários são reduzidos e o preço da vida é mais barato. Seguindo esta linha de raciocínio, para a mesma época a realidade colonial rio-platense deveria ser descrita em termos muito próximos ao que se identificou no litoral brasileiro ao longo dos séculos XVI e XVII. No entanto, o quadro de análise é funcional sob a perspectiva do europeu. O exame mais aproximado de ambas as sociedades faz com que distinções importantes sejam constatadas e, a cada passo de aprofundamento no debate comparativo de reflexões entre Aldo Ferrer e Celso Furtado, descobrem-se as peculiaridades distintivas de cada ordenamento americano. Os dados explicitados no estudo de Aldo Ferrer permitem uma elaboração mais precisa sobre a questão da suposta homogeneidade na periferia da divisão internacional do trabalho.

\section{Ferrer e o espaço aberto argentino}

Conforme mencionado, uma gama de estudos influenciam o teórico argentino, entre os quais consta o de Celso Furtado. A importância do autor brasileiro também é notória nos exemplos em que narra a formação econômica do território Rio-platense,

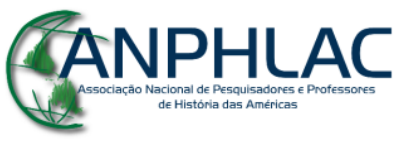

Revista Eletrônica da ANPHLAC, ISSN 1679-1061, №. 23, p. 285-313, Jul./Dez., 2017. http://revista.anphlac.org.br 
porque a realiza em diálogo com a produção nacional e com a de seu interlocutor. Um dos pontos distintos da formação colonial na perspectiva de Ferrer consiste no caráter minerador da economia colonial espanhola. Furtado, por sua vez, descreve a construção de uma zona produtiva açucareira que consegue se inserir nos mercados de produtos tropicais. De acordo com o brasileiro, Portugal cria uma empresa agrícola no litoral da sua colônia e a produção realizada é bem sucedida na perspectiva dos lusitanos durante o intervalo de tempo correspondente aos séculos XVI e XVII. Lembra-se que, no mesmo período, inicia-se a maior diáspora africana para a América do Sul. No caso rioplatense, os espanhóis se apoderam de recursos minerais que estavam, em um primeiro momento, sob o domínio de sociedades originárias do continente. Então, a economia extrativa é central no quadro administrativo, com destaque para o saque de recursos e a exploração do trabalho da população nativa americana. Ferrer atenta para um traço que singulariza a experiência espanhola na América: a particularidade no que tange ao fato de ser a única metrópole europeia que utilizou de forma predominante o trabalho indígena:

\begin{abstract}
El imperio español era el que contaba con más abundancia de fuerza de trabajo indígena aprovechable y su movilización hacia la producción fue el principal objeto de la política colonial y de los colonizadores. Las tradicionales organizaciones de la mita y el yaconazgo, entre otras, regulaban las relaciones de los trabajadores indígenas con la empresa productiva.

Prácticamente ninguna de las otras naciones coloniales contó con una oferta preexistente de mano de obra como fue el caso de España. Por lo tanto, Portugal, Inglaterra, Francia y Holanda debieron traer la mano de obra desde otros lugares. Tuvo asi lugar la inmigración de población blanca en condiciones serviles, como los indentured servants en las colonias inglesas del norte, y, fundamentalmente, la importación de esclavos, que se concentró particularmente en las costas del Caribe, las Antillas y el Brasil. ${ }^{8}$ (FERRER, 1963, p. 26)
\end{abstract}

No fragmento, ressalta-se a identificação de uma regularidade a respeito das demais potências europeias. Esta é uma peculiaridade na história nacional que o autor

\footnotetext{
${ }^{8}$ Tradução livre: O império espanhol era o que contava com mais abundancia em força de trabalho indígena aproveitável e sua mobilização para a produção foi o principal objetivo da política colonial e dos colonizadores. As tradicionais organizações da Mita e do Yaconazgo, entre outras, regulavam as relações dos trabalhadores indígenas com a empresa produtiva. Praticamente, nenhuma das outras nações coloniais contou com uma oferta preexistente de mão de obra, como foi o caso da Espanha. Por isso, Portugal, Inglaterra, França e Holanda precisaram trazer a mão de obra de outros lugares. Ocorreu a imigração de população branca em condições servis, como os indentured servants nas colônias inglesas do norte e principalmente a importação de escravos, que se concentrou particularmente no Caribe, nas Antilhas e no Brasil.
}

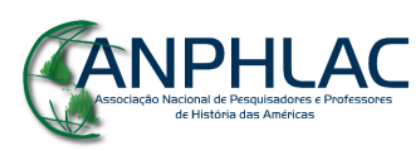

Revista Eletrônica da ANPHLAC, ISSN 1679-1061, №. 23, p. 285-313, Jul./Dez., 2017. http://revista.anphlac.org.br 
vincula à Espanha. No presente trabalho, opta-se por selecionar a passagem acima, porque a especificidade castelhana é cotejada com outros países, mas a questão extrapola a simples comparação. Na obra mencionada, John Elliott também enfatiza tal estrutura e aponta para a ação espanhola de utilização do espaço, das hierarquias de poder e da mão de obra indígena em uma proporção que supera em muito o emprego dos povos nativos americanos pelos portugueses. À luz de sua perspectiva, conclui-se que a América lusitana dificilmente teria população indígena suficiente para aplicar o sistema de encomiendas. Na estrutura administrativa dos castelhanos, os métodos do trabalho indígena que antecedem à Conquista como a Mita e o Yaconazgo do ViceReino do Peru se preservam. Este fator favoreceu a criação de uma administração pública e uma ordenação do trabalho bem diferenciada de outras estruturas, sejam elas peninsulares ou luso-americanas (ELLIOTT, 2012, p. 24).

Os recursos minerais da América espanhola eram extraídos através dos esforços da população originária. ${ }^{9}$ Como visto em Furtado no caso do Brasil, por sua vez, o ciclo minerador organizou a produção ancorada em mão de obra cativa no século XVIII. Ainda no campo colonial, reafirma-se que Ferrer defende a subordinação do espaço referente à Argentina à zona marginal do comércio do Vice-Reino do Peru. As áreas dinâmicas do que veio a se tornar um país, as províncias de Tucumán e Salta forneceram mulas e peças de vestuário às tropas que seguiam o caminho da mineração em Potosí. O restante do território ocupava-se de economia de subsistência e estava distanciado das grandes rotas comerciais coloniais. Tais aspectos sustentam a interpretação de que a formação da economia argentina, por outra perspectiva, associouse às zonas cujo impacto econômico dos sistemas mercantis ibéricos foi menor.

Sea cual fuere la naturaleza de las actividades de exportación y de las estructuras sociales apoyadas en ellas, las regiones que más se desarrollaron durante la América colonial fueron aquellas donde se asentaron las actividades exportadoras, mientras que las que se dedicaron a satisfacer el consumo interno o su propia subsistencia tuvieron poca importancia relativa dentro de la economía de la época. Perú, México, las colonias inglesas del Norte, las Antillas y el nordeste del Brasil son casos típicos de la primera experiencia, el actual territorio argentino, de la segunda. De las actividades destinadas al mercado interno, sólo las que de alguna manera se vincularon con un centro dinámico exportador experimentaron cierto grado de

\footnotetext{
${ }^{9}$ Wanderley (2015) e Queija (1999) questionam o predomínio absoluto da mão de obra indígena nos primeiros momentos da colonização espanhola. Também é fundamental atentar para a dimensão expressiva das populações de ascendência africana nos domínios castelhanos nos século XVI e XVII.
}

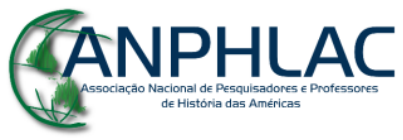

Revista Eletrônica da ANPHLAC, ISSN 1679-1061, №. 23, p. 285-313, Jul./Dez., 2017. http://revista.anphlac.org.br 
desarrollo. En la Argentina, por ejemplo, la producción de mulas en el Litoral destinadas a las minas de Potosí y la producción de paños en Tucumán con el mismo destino fueron las pocas actividades desarrolladas en nuestro territorio, entre el siglo XVI y la primera mitad del siglo XVIII, que gozaron de alguna prosperidad. ${ }^{10}$ (FERRER, 1963, p. 32)

Quando descreve o contexto citado, Ferrer evidencia a presença limitada do sistema colonial espanhol, principalmente no período analisado dos séculos XVI e XVII. A noção de região argentina na periferia se refere à parte marginal da estrutura administrativa espanhola na área sul-americana, ou seja, um local da colônia pouco transitado. O posicionamento afastado do espaço colonial do território dialoga com as premissas do desenvolvimentismo dos anos 1960-70. No início do século XX, a Argentina se destacou na porção austral do continente americano por sua expansão industrial e pela formação de estratos sociais médios em números relevantes. ${ }^{11}$ Em vista disso, os intelectuais observaram seus territórios como pouco marcados, ou até mesmo livres, pelos entraves decorrentes das formações sociais herdadas do período de dominação ibérica. Isto é, as estruturas coloniais com menos relevância impulsionam o capitalismo, pois se expandem sem a sombra do passado. Por outro lado, no início do século XVII, o complexo açucareiro era a porção mais rentável do império português. $\mathrm{O}$ litoral brasileiro tornou-se sede da administração colonial e, em 1808, a estrutura administrativa lusitana buscou abrigo em sua colônia. Sendo assim, as instituições ibéricas tiveram centralidade na porção citada do continente. Em contraponto, segundo Ferrer, a Argentina constitui-se como uma região livre para o avanço das instituições do capital ao passo que o Brasil e o restante do continente estavam mais permeados pela herança de regimes mercantis ibéricos.

\footnotetext{
10 Tradução livre: Há muitos fatores que separam as sociedades coloniais espanholas daquilo que conhecemos como o Estado Nacional Latino-americano atual. No decorrer de séculos, ocorreram mudanças em muitos aspectos como dimensão territorial, origem da população, cultura nacional e sistema de governo. Sendo assim, a área do império espanhol do Rio da Prata se diferencia muito do que se conhece hoje em dia como Argentina. Das atividades destinadas ao mercado interno, experimentaram algum crescimento somente as que se vincularam a um centro dinâmico de exportação. Na Argentina, por exemplo, a produção de mulas do litoral, destinadas às minas de Potosí, e a de tecidos em Tucumán, com o mesmo destino, estiveram entre as poucas desenvolvidas em nosso território entre o século XVI e a primeira metade do século XVIII, que gozaram de certa prosperidade.

${ }^{11}$ Estes autores oferecem dados que sustentam as afirmações resumidas neste parágrafo e no subsequente: BERTOLA; OCAMPO 2013, p. 164; FURTADO, 1976, p. 132-144; FAUSTO; DEVOTO, 2009, p. 151; RAPPOPORT, 2003, p. 1057.
}

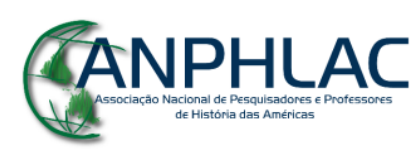

Revista Eletrônica da ANPHLAC, ISSN 1679-1061, №. 23, p. 285-313, Jul./Dez., 2017. http://revista.anphlac.org.br 
Em outro viés, a ideia de espaço aberto é menos visível. Segundo Brading, a criação do Vice-Reino do Prata foi proposta pelo governo ilustrado dos Bourbons para fiscalizar o comércio de Prata. Em 1750, no tratado de Madrid, procurou-se uma solução para os conflitos territoriais que surgiam desde o início do século XVIII. Assim, Buenos Aires tornou-se sede de um vice-reinado espanhol oficialmente em 1776 e esta ação reconhece um grau de dinamismo elevado que a cidade já demonstrava desde o início daquele século (BRADING, 2012, p. 405). Então, a leitura que diminui seu pertencimento ao império espanhol confere pouca importância às ações dos últimos períodos do domínio castelhano e atribui um valor menor ao seu posto vice-reinal. Esta suposta importância secundária é valorizada positivamente em dois pontos: recebe uma estrutura administrativa colonial menor e dota a região de uma dinâmica nacional responsável pela formação embrionária do mercado interno.

\section{Notas Conclusivas}

Os pontos mais marcantes das narrativas de Furtado e Ferrer dos séculos XVI e XVII aqui elencados são as explorações econômicas nacionais que desenvolvem e as formas de emprego de mão de obra local. A formação do complexo açucareiro de um lado se contrasta com a opção pela economia mineradora de outro. No entanto, as questões econômicas de constituição do mercado interno nacional pautam o discurso de ambos e respondem por seus interesses prioritários.

No que tange à nossa reflexão, contextualizou-se o cenário descrito com o Sistema Mundo de Braudel, o que contribuiu para uma avaliação mais holística de Sistema Mundo. Através da análise comparada, evidenciam-se as marcas de pertencimento subordinado da região sul-americana, como o trabalho compulsório e a vida pouco monetarizada. Porém, os itens de sobrevivência das tradições nativas e a hierarquia de poder ibérico diferenciam a divisão de trabalho, contrariando, parcialmente, o componente que prevê aumento da uniformidade ao se afastar do centro do Sistema.

Nas obras analisadas, o litoral brasileiro obteve destaque na colonização portuguesa. Em contraponto, o território rio-platense ocupou um espaço secundário no império castelhano, uma vez que o baixo Peru respondia pelo posto preponderante. $\mathrm{O}$

\section{CANPHLAC}

Revista Eletrônica da ANPHLAC, ISSN 1679-1061, №. 23, p. 285-313, Jul./Dez., 2017. http://revista.anphlac.org.br 
autor argentino identificou a economia de sua nação como originária de um fluxo comercial colonial. Desta forma, as estruturas econômicas presentes abasteciam o mercado interno, local e colonial. Já no caso brasileiro, a cultura do açúcar se direcionava prioritariamente ao mercado europeu e era atravessada pela intermediação dos comerciantes portugueses, de maneira que seu impulso formativo consistiu em monocultora tropical e estava destinada ao mercado externo. No momento assinalado, a mão de obra predominante no caso brasileiro era sustentada pelo sistema escravagista, em oposição ao caso hispano-americano, marcado por sociedades nativas. Evidenciouse, no debate, que os historiadores econômicos empenharam seus esforços na análise de singularidades no quadro econômico dos espaços nacionais.

Durante um longo tempo, as histórias econômicas de Brasil e Argentina estiveram aproximadas pelo pertencimento aos sistemas coloniais ibéricos, uma vez que tais sociedades estavam situadas em pontos próximos do mesmo continente. Além disso, lembra-se que ambas estabeleceram seus pilares no sistema agrícola de exportação. Nas décadas entre 1950-1960, outros aspectos também foram observados, como as questões que concernem ao subdesenvolvimento e ao esforço para examinar itens formativos da nação e, consequentemente, equacionar as marcas do atraso que conduziam a classificação dos países na categoria subalterna da divisão do trabalho internacional. Neste estudo comparativo, atentou-se para as bases econômicas diferenciadas dos países no período colonial retratado por dois autores de forma integrada ao panorama internacional e contextualizada com as questões de sua época.

Em classificações gerais do Sistema Mundo europeu, Brasil e Argentina são situados de maneira próxima, ambos se posicionam em regiões distantes do centro europeu e produzem bens elementares sob condições de trabalho degradadas. Entretanto, basta perscrutar a realidade da produção histórica de cada um que as diferenças políticas, econômicas e sociais se evidenciam. Creio que a comparação proposta tenha contribuído para que os contrastes gritem e impeçam, ao menos pontualmente, que ambas as nações e todo o restante do continente latino-americano sejam observados como um grande espaço comum.

\section{CANPHLAC}

Revista Eletrônica da ANPHLAC, ISSN 1679-1061, №. 23, p. 285-313, Jul./Dez., 2017. http://revista.anphlac.org.br 


\section{Referências Bibliográficas}

\section{Fontes}

FERRER, Aldo. La Economía Argentina: las etapas de su desarrollo y problemas actuales. México-Buenos Aires. Fondo de Cultura Económica. 1963.

FURTADO, Celso. Formação econômica do Brasil. Rio de Janeiro, Editora fundo de Cultura S.A., 1963.

\section{Bibliografia}

ALIMONDA, Hector. Paz y Administración - Ordem e Progresso: Economia exportadora e formas políticas na Argentina e no Brasil (1880/1930). Tese Doutorado em Ciências Políticas da Faculdade de Filosofia, Letras e Ciências Humanas, Universidade de São Paulo, São Paulo, 1982.

BÉRTOLA, Luis; OCAMPO, José Antonio. Desarrollo, Vaivenes y desigualdad: una historia económica de América Latina desde la independencia. México: Fondo de cultura econômica, 2013.

BLOCH, Marc. História e Historiadores. Lisboa: Teorema, 1998.

BLOCH, Marc. Os reis taumaturgos. São Paulo: Companhia das Letras, 1993.

BRADING, D. A. A Espanha dos Bourbons e seu Império Americano. In: BETHELL, Leslie. América Latina colonial. Volume I. São Paulo: EDUSP, 2012.

BRAUDEL, Fernand. Civilização Material, Economia e Capitalismo nos séculos XVXVIII. Vol. 3, Cap. A divisão do espaço e do tempo na Europa. In: Escritos sobre a história. São Paulo. Perspectiva, 1978.

BRAUDEL, Fernand. O mediterrâneo e o mundo mediterrâneo na época de Felipe II. $2^{a}$ edição. Lisboa: Publicações Dom Quixote, 1995.

BRESSER-PEREIRA, Luis Carlos. As três interpretações da dependência. Perspectivas, São Paulo, v. 38, p. 17-48, jul./dez. 2010.

BURKE, Peter. A escola dos Annales 1929-1989: A revolução francesa da historiografia. São Paulo: Editora UNESP, 2010.

CAPELATO, Maria Helena R. Multidões em Cena. Propaganda Política no Varguismo e no Peronismo. Campinas: Papirus, 1998.

CARDOSO, Fernando Henrique. FALETTO, Enzo. Dependência e Desenvolvimento na América Latina: Ensaio de Interpretação Sociológica. $7^{\text {a }}$ ed., Rio de Janeiro: Editora LTC, 1970.

D'ARBO, Renata Cipolli. Inadequação Tecnológica e Subdesenvolvimento: As Abordagens de Raúl Prebisch, Ragnar Nurkse e Celso Furtado nos Anos 50. VII

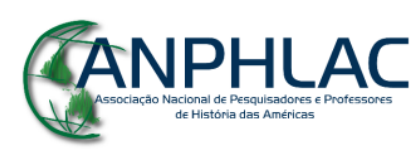

Revista Eletrônica da ANPHLAC, ISSN 1679-1061, №. 23, p. 285-313, Jul./Dez., 2017. http://revista.anphlac.org.br 
Encontro Nacional de Economia Política e II Colóquio Latino Americano de Economistas Políticos. Curitiba, 2002.

DEVOTO, Fernando; FAUSTO, Boris. Argentina Brasil 1850-2000. Un Ensayo de Historia Comparada. Buenos Aires: Ed. Sudamericana, 2009.

DONGHI, Tulio Halperin. Historiografia colonial hispano-americana e multiculturalismo: a história da colonização entre a perspectiva do colonizador e a do colonizado. Estudos Históricos, Rio de Janeiro, vol. 10, n. 20, 1997.

ELLIOTT, John. El Atlántico español y el Atlántico luso: divergencias y convergencias. Las Palmas. XX Coloquio de Historia Canario-Americana, 2012.

ESCOBAR, Arturo. La Invención del tercer mundo. Construcción y desconstrucción del desarrollo. Caracas: Edición Fundación Editorial el Perro y la Rana, 2007.

FERRER, Aldo. Vivir con lo nuestro: para romper la trampa financiera y construir la democracia. Buenos Aires: El Cid Editor, 1983.

FERRER, Aldo; JAGUARIBE, Helio; SANTOS, Theotonio dos; WIONCZEK, Miguel S. La dependencia político-económica de América Latina. Ciudad de México: Siglo veintiuno editores, 1977.

FERRER, Aldo; PREBISCH, Raúl; FURTADO, Celso. Para construir la democracia o deuda y soberanía. Buenos Aires: El Cid Editor/Fundación para la Democracia en la Argentina, 1984.

FERRER, Aldo. La Economía Argentina: desde sus Orígenes hasta principios del siglo XXI. Buenos Aires: Fondo de Cultura Económica. 2004.

FURTADO, Celso. Uma Economia dependente. Rio de Janeiro: Ministério de educação e cultura. 1956.

FURTADO, Celso. Formación económica del Brasil. México-Buenos Aires. Fondo de Cultura Económica, 1962.

FURTADO, Celso. A hegemonia dos Estados Unidos e o subdesenvolvimento da América Latina. Rio de Janeiro: Civilização Brasileira. 1973.

FURTADO, Celso. Formação econômica do Brasil. São Paulo: Companhia Editora Nacional, 1974.

FURTADO, Celso. La economía latinoamericana: formación histórica y problemas contemporáneos. Ciudad de México: Siglo Veintiuno Editores, 1976.

FURTADO, Celso. A economía Latino-Americana. São Paulo: Companhia Editora Nacional, 1978.

FURTADO, Celso. O mito do desenvolvimento econômico. Rio de Janeiro: Paz e Terra. 1996.

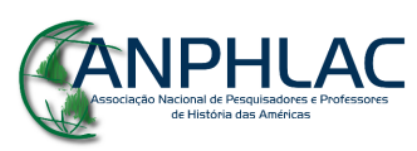

Revista Eletrônica da ANPHLAC, ISSN 1679-1061, №. 23, p. 285-313, Jul./Dez., 2017.

http://revista.anphlac.org.br 
GARCIA, Afrânio. La construction interrompue: Celso Furtado, la guerre froide et le développement du Nordeste. Actes de la Recherche en Science Sociales. Vol. 121-122, mars, 1998. Les ruses de la raison impérialiste. p. 52-61.

GARCIA, Afrânio. A dependência da política: Fernando Henrique Cardoso e a sociologia no Brasil. Tempo Social, Brasil, v. 16, n. 1, p. 285-300, jun. 2004. Disponível em: http://www.revistas.usp.br/ts/article/view/12426 Acesso em: 12 de agosto de 2015.

GRUZINSKI, Serge. A colonização do imaginário: sociedades indígenas e ocidentalização no México espanhol. Séculos XVI-XVII. São Paulo: Companhia das Letras, 2003.

GRUZINSKI, Serge. A águia e o dragão: ambições europeias e mundialização no século XVI. São Paulo: Companhia das letras, 2015.

LORA, Jorge; MALLORQUÍN, Carlos. Prebisch y Furtado: El estructuralismo latinoamericano. Puebla, México: Benemérita Universidad Autónoma de Puebla, 1999.

MACEDO, Bernardo Gouthier. Prebisch e Furtado: a economia política cepalina do economicismo à cultura. VII Encontro Nacional de Economia Política, Curitiba: SEP, 2002.

PRADO, Maria Ligia Coelho. Repensando a história comparada da América Latina. Revista de História, São Paulo, n. 153, p. 11-33, dec. 2005.

PRADO, Maria Ligia Coelho. América Latina: História Comparada, Histórias Conectadas, História Transnacional. Anuário - Universidad Nacional de Rosário, v. 24, p. 9-22, 2013.

PRADO, Maria Ligia Coelho. A revista Cadernos do Nosso Tempo e a formulação do projeto desenvolvimentista. In: CRESPO, Regina (Org.). Revistas en América Latina: proyectos literarios, políticos y culturales. $1^{\mathrm{a}}$ ed. Ciudad de México: Ediciones León, 2010.

PREBISCH, Raúl. Capitalismo periférico: crisis y transformación. México D.F.: Fondo de Cultura Económica, 1981.

QUEIJA, Berta Ares; STELLA, Alessandro (Coord.). Negros, mulatos, zambaigos: derroteros africanos en los mundos ibéricos. España. CSIC - Escuela de Estudios Hispano-Americanos, 2000.

RIBEIRO, Vanderlei Vazelesk. A Roça y La Campana: A questão agrária sob o Varguismo e o Peronismo em perspectiva comparada. Tese Doutorado em História. Instituto de Ciências Humanas e Filosofia, Universidade Federal Fluminense, Niterói, 2006.

ROUGIER, Marcelo. Aldo Ferrer y sus días. Ideas, trayectoria y recuerdos de un economista. Conversaciones. Buenos Aires: Linguaje Claro Editora, 2014.

SILVA, Ana Paula Barcelos Ribeiro da. Diálogos sobre a escrita da história: Brasil e Argentina (1910-1940). Brasília: Fundação Alexandre de Gusmão. 2011.

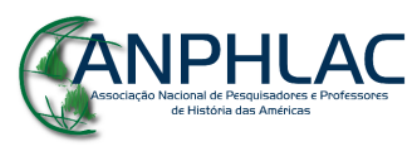

Revista Eletrônica da ANPHLAC, ISSN 1679-1061, №. 23, p. 285-313, Jul./Dez., 2017.

http://revista.anphlac.org.br 
SOUZA, Davisson C. C. Sindicalismo e desempregados no Brasil e na Argentina 19902002. Tese de doutorado em sociologia. USP. São Paulo. 2010.

STEDILE, João Pedro; TRASPADINI, Roberta (Orgs.). Ruy Mauro Marini: Vida e obra. São Paulo: Expressão Popular, 2001.

STEIN, Staley J.; STEIN, Barbara H. A herança colonial da América Latina: Ensaios de dependência econômica. Rio de Janeiro: Editora Paz e Terra, 1983.

VALDÉS, Eduardo Devés. El pensamiento latinoamericano en el siglo XX. Tomo II. Desde la CEPAL al neoliberalismo (1950-1990). Santiago, Chile: Editorial Biblos Centro de Investigaciones Diego Barros Arana, 2003.

WANDERLEY, M. R.; CASARES, A. M.; GONZÁLEZ, F. M. Mulatos libres, redes personales y cogniciones en la Nueva España (siglos XVII-XVIII). In: CASARES, Aurelia Martín; GONZÁLEZ, Francisco Montes (Orgs.). Esclavitud, mestizaje y abolicionismo en el mundo hispánico. $1^{\mathrm{a}}$ ed. Granada: Universidad de Granada, 2015.

\section{GANPHLAC}

Revista Eletrônica da ANPHLAC, ISSN 1679-1061, №. 23, p. 285-313, Jul./Dez., 2017.

http://revista.anphlac.org.br 